\title{
Drug Solubility and Dissolution Thermodynamic Approach in Various Solvents at Different Temperatures: A Review
}

\author{
Ravibhai Bhola $^{1(\mathbb{D})}$, Hasit Vaghani $\left.1, * \mathbb{( \mathbb { D }}\right)$, Keyur Bhatt ${ }^{1, *(\mathbb{D})}$, Rizwan Ghumara ${ }^{2 \mathbb{D}}$ \\ 1 Department of Chemistry, Ganpat University, Gujarat-384012, India \\ 2 Department of Chemistry, Kadi Sarva Vishvavidyalaya, Gujarat-382024, India \\ * Correspondence: hvv01@ganpatuniversity.ac.in (H.V.);
}

Scopus Author ID 53980703900

Received: 19.06.2021; Revised: 25.07.2021; Accepted: 30.07.2021; Published: 15.08.2021

\begin{abstract}
In chemical science, pharmaceutical, food science, petrochemicals, and material science, the solubility parameter is one of the most important factors. The studies of solubility and thermodynamics properties are directly used in crystallization-recrystallization, purification of yields, low toxicity of solvent or green solvent, modification, and many more. The experimental mole fraction solubility of compounds may be determined by various methods such as static gravity, laser dynamic, isothermal equilibrium, shake flask, and a number of other ways. The present review is focusing on the shake flask method. Further, the experimental mole fraction solubility was correlated with a theoretical model such as the Appellate and Buchowski equations. With the help of model correlation such as the Relative Average Deviation (RAD), Absolute Relative Deviation (ARD), and Root Mean Square Deviation (RMSD) for prediction of the best model fitting in theoretical approach. The Van't Hoff equation is most effective in the prediction of the dissolution thermodynamic factors such as $\Delta H^{\circ}$ (mixing enthalpy change), $\Delta G^{\circ}$ (mixing Gibbs energy change), and $\Delta S^{\circ}$ (mixing entropy change). It had been given consequence details about endothermic or exothermic and entropy drive, which was directly applied in industrial production and purification of the drug.
\end{abstract}

Keywords: solubility; shake flask method; Apelblat and Buchowski equation; dissolution thermodynamic.

(C) 2021 by the authors. This article is an open-access article distributed under the terms and conditions of the Creative Commons Attribution (CC BY) license (https://creativecommons.org/licenses/by/4.0/).

\section{Introduction}

Solubility is the most important term in chemical science, physics, pharmaceutical, food science, petrochemicals, and material science. The solubility and related dissolution thermodynamics parameters $\left(\Delta G^{\circ}, \Delta H^{\circ}, \Delta S^{\circ}\right)$ are effective in the modification and design or separation process in pharmaceutical, chemical, food industry, and many more [1-3]. The solubility has been given particular statics data of solute solubility in solvents is asserted in the process of crystallization-recrystallization and improve the yield of products $[4,5]$. The process of crystallization-recrystallization effect on the nature of solute and solvents and interaction of solute and solvent and other factors affected [6].

The solubility may be delineated as the most extent of solute that can be completely dissolved in a given proportion of solution at a certain temperature. The solubility of a compound may be described in various units, and each unit, which showed in Table 1, represents the quantity of solute dissolved in solvents at a specified temperature [7]. 
Table 1. The units described the amount of pure solute dissolved in a pure solvent at a specified temperature.

\begin{tabular}{|c|c|c|c|c|}
\hline Sr.No. & Term & Definition & Equation & Application \\
\hline \multirow[t]{3}{*}{1} & Solution & $\begin{array}{l}\text { If the supreme amount of solute } \\
\text { is dissolved in a given solvent at } \\
\text { a particular temperature is } \\
\text { known as a saturated solution. }\end{array}$ & \multirow[t]{3}{*}{$\mathrm{S}=$ solvent + solute } & \multirow{12}{*}{$\begin{array}{l}\text { - It is used in } \\
\text { pharmaceuticals } \\
\text { - } \quad \text { In food science } \\
\text { - Most important } \\
\text { in } \\
\text { - Chemical } \\
\text { science } \\
\text { - In } \\
\text { petrochemicals } \\
\text { - It is widely used } \\
\text { in material } \\
\text { science and } \\
\text { many more. }\end{array}$} \\
\hline & & $\begin{array}{l}\text { If the solute concentration is } \\
\text { lesser than the saturated solution } \\
\text { at a given temperature is called } \\
\text { an unsaturated solution. }\end{array}$ & & \\
\hline & & $\begin{array}{l}\text { Under specific conditions, a } \\
\text { metastable solution can be } \\
\text { prepared, known as a } \\
\text { supersaturated solution. }\end{array}$ & & \\
\hline 2 & Molarity & $\begin{array}{l}\text { The molarity of the solution is } \\
\text { denominated by the M symbol. } \\
\text { The number of moles of solute } \\
\text { per liter solution. }\end{array}$ & $\begin{array}{c}\mathrm{M}={ }^{n} / V \\
\frac{\text { mole }}{\text { litter }} \text { or } \frac{\text { mole }}{d m^{3}}\end{array}$ & \\
\hline 3 & Mole & $\begin{array}{l}\text { The moles are shown by the } n \\
\text { symbol, and the weight of an } \\
\text { individual compound upon the } \\
\text { molecular weight of the } \\
\text { compound is known as a mole of } \\
\text { that particular compound. }\end{array}$ & $\mathrm{n}=W_{1} / M . W$ & \\
\hline 4 & Normality & $\begin{array}{l}\text { The normality is shown by } \mathrm{N} \text {. } \\
\text { The normality of the solution is } \\
\text { expressed by the number of the } \\
\text { equivalent of solute dissolved in } \\
\text { a liter of solution. The equivalent } \\
\text { is equal to the number of grams } \\
\text { upon its equivalent weight. }\end{array}$ & $\begin{array}{c}\mathrm{N}={ }^{W_{1}} / E_{1} \times V \\
\text { eq. } / L_{\text {or }} \\
\text { eq. } / d m^{3}\end{array}$ & \\
\hline 5 & Molality & $\begin{array}{l}\text { The molality is expressed by the } \\
\mathrm{m} \text { symbol. The whole number of } \\
\text { mole of solute per kilogram } \\
\left(10^{-3}\right) \text { solvent. }\end{array}$ & $\mathrm{m}={ }^{n} / S_{1}$ & \\
\hline 6 & Mole fraction & $\begin{array}{l}\text { The correspondence ratio of the } \\
\text { number of mole of singular } \\
\text { component upon total moles. } \\
\text { The total mole of all compounds } \\
\text { present is always equal to } 1 \text { in } \\
\text { the solution. }\end{array}$ & $\begin{array}{c}\mathrm{X}_{\mathrm{a}}=n_{a} / n_{a}+n_{b} \\
X_{b}=n_{b} / n_{a}+n_{b} \\
n_{a}+n_{b}=1\end{array}$ & \\
\hline 7 & $\begin{array}{c}\text { Weight } \\
\text { percentage }\end{array}$ & $\begin{array}{l}\text { It is express by } \% w / w \text { symbol. } \\
\text { The numbers of a gram of solute } \\
\text { dissolved in } 100 \text { grams of } \\
\text { solution. }\end{array}$ & $\% w / w=w_{2} / w_{3}$ & \\
\hline 8 & $\begin{array}{c}\text { Volume } \\
\text { percentage }\end{array}$ & $\begin{array}{l}\text { It is express by } \% v / v \text { symbol. } \\
\text { The numbers of a millilitre of } \\
\text { solute dissolved in } 100 \\
\text { millilitres of solution. }\end{array}$ & $\% v / v=v_{2} / v_{3}$ & \\
\hline 9 & $\begin{array}{l}\text { Weight- } \\
\text { volume } \\
\text { percentage }\end{array}$ & $\begin{array}{l}\text { It is express by } \% w / v \text { symbol. } \\
\text { The numbers of grams of solute } \\
\text { dissolved in } 100 \text { millilitres of } \\
\text { solution. }\end{array}$ & $\% w / v=w_{2} / v_{3}$ & \\
\hline 10 & Ppm & $\begin{array}{l}\text { The parts pert per million is } \\
\text { signify by Ppm. It may be } \\
\text { revealed as the total amount of } \\
\text { the solute dissolved in } 10^{6} \text { equal } \\
\text { units of solution. }\end{array}$ & $\begin{array}{c}\mathrm{Ppm}=\% w / v \times \\
10000 \text { or } \% v / v \times \\
10000 \text { or } \% w / w \times \\
10000\end{array}$ & \\
\hline
\end{tabular}

Here, $\mathrm{n}=$ the numbers of the moles of solute, M. W. = molecular weight of - the solute, $\mathrm{E}_{1}=$ equivalent weight of the solute, $S_{1}=$ weight of the solvent in the kilogram, $X_{a}=$ mole fraction of solute, $\mathrm{X}_{\mathrm{b}}=$ mole fraction of the solvent, $\mathrm{n}_{\mathrm{a}}=$ the numbers of the moles of solute, $\mathrm{n}_{\mathrm{b}}=$ the numbers of the moles of solvent, $\mathrm{w}_{1}=$ weight of the solute, $\mathrm{V}=$ volume of the solution in a litter. 


\section{Materials and Methods}

\subsection{Measurement of solubility.}

\subsubsection{The shake flask method.}

Solubilities were determined by a shake-flask method [6, 8-14] along with spectrophotometric analysis. The approximate amount of compound (i.e. 20 to $50 \mathrm{gm}$ ) is added to each pure or binary solvent mixture in stoppered glass flasks. These flasks were put down into the ultrasonic bath or thermostat to maintain the specific temperature for at least ( 2 to 5 days) to achieve the solid-liquid equilibrium in solute and solvent. After the saturation or equilibrium, the solutions had been filtered at the isothermal conditions. Before sampling, it was ensured that the solution is free of solvent or other particles of matter. Then compound or drug concentrations were investigated using UV spectrophotometry titration with $\mathrm{NaOH}(0.10$ $\mathrm{N})$ at a specified wavelength. Above all, the solubility investigations were carried out a minimum of three times. Then the increase in temperature difference is taken as 5 Kelvin in thermostat, followed by similar steps referred as above.

The mathematical representation of the experimental mole fraction solubility $(x)$ of a compound in each pure solvent can be expressed by using equation number (1).

$$
x=\frac{m_{1} / M_{1}}{m_{1} / M_{1}+{ }^{m_{2}} / M_{2} \ldots \ldots . . \sum_{n}^{i} m_{i} / M_{i}}
$$

where, $m_{1}$ is the mass of solute, $m_{2}$ is the solvent's mass and $M_{1}, M_{2}$ are the molar masses of solute and solvent, respectively.

Table 2 depicts the measurement of experiment mole fraction solubility in various solvent systems and at different temperatures by various researchers.

Table 2. Measurement of experimental mole fraction solubility in the various solvent system and different

\begin{tabular}{|c|c|c|c|c|c|c|}
\hline \multirow[b]{2}{*}{$\begin{array}{l}\text { Sr. } \\
\text { No. }\end{array}$} & \multicolumn{5}{|c|}{ temperatures. } & \multirow[b]{2}{*}{ Reference } \\
\hline & Name & $\begin{array}{l}\text { Name of } \\
\text { Compound }\end{array}$ & Use of Solvent & $\begin{array}{c}\text { Temperature } \\
\text { range } \\
\text { in Kelvin } \\
\end{array}$ & Observation & \\
\hline 1 & $\begin{array}{l}\text { Fleming } \\
\text { M. et al. }\end{array}$ & meloxicam & $\begin{array}{l}\text { (formamide+ water), }(\mathrm{N}- \\
\text { methylformamide+water }),( \\
\mathrm{N}, \mathrm{N}- \\
\text { dimethylformamide+water }) \\
\text { binary mixture use }\end{array}$ & $\begin{array}{c}293.15 \\
\text { to } \\
313.15\end{array}$ & $\begin{array}{l}\text { Solubility was risen up as } \\
\text { temperature, and co-solvent amount } \\
\text { part arises. } \\
\text { Maximum solubility was obtained in } \\
(N, N \text {-dimethylformamide +water) } \\
\text { binary solvent system. }\end{array}$ & [8] \\
\hline 2 & $\begin{array}{l}\text { Fleming } \\
\text { M. et al. }\end{array}$ & Sulfadiazine & $\begin{array}{l}\text { (Ethylene glycol+ water) } \\
\text { binary solvent system use }\end{array}$ & $\begin{array}{c}278.15 \\
\text { to } \\
318.15\end{array}$ & $\begin{array}{l}\text { Solubility in mole fraction was } \\
\text { increased in order to increase in } \\
\text { temperature. It is also found that } \\
\text { ethylene glycol proportion is } \\
\text { enhanced as solubility increased. }\end{array}$ & [9] \\
\hline 3 & $\begin{array}{l}\text { Hongkum } \\
\quad \text { et al. }\end{array}$ & $\begin{array}{l}\text { 2-Amino-6- } \\
\text { chlorobenzoic } \\
\text { acid }\end{array}$ & $\begin{array}{l}\text { Ethylene glycol(EG), } N \text { - } \\
\text { methyl } \\
\text { pyrrolidone(NMP),acetonitr } \\
\text { ile,n-propanol, } n \text { - } \\
\text { heptanol,isobutanol,water,t } \\
\text { oluene,ethanol,isopropanol, } \\
\text { cyclohexane,ethyl acetate,1- } \\
\text { ocatanol pure solvents use }\end{array}$ & $\begin{array}{l}278.15 \\
\text { to } \\
323.15\end{array}$ & $\begin{array}{l}\text { The solubility was increased along } \\
\text { with an increase in temperature, and } \\
\text { the mole fraction of the solubility } \\
\text { was maximum and minimum in } \\
\text { NMP and cyclohexane, respectively }\end{array}$ & {$[6]$} \\
\hline 4 & $\begin{array}{l}\text { Hongkum } \\
\text { et al. }\end{array}$ & $\begin{array}{c}\text { 5,7-dibromo-8- } \\
\text { hydroxyquinoline }\end{array}$ & $\begin{array}{l}\text { Methanol, ethane, } \\
\text { isopropanol ,n-propanol, } \\
N, N \text {-dimethyl amide, } n \text { - } \\
\text { butanol, acetone, toluene, } \\
\text { ethyl acetate,1,4-dioxane,1- } \\
\text { methyl-2-pyrrolidinone, 2- } \\
\text { butanol pure solvents use }\end{array}$ & $\begin{array}{l}288.15 \\
\text { to } \\
328.15\end{array}$ & $\begin{array}{l}\text { Solubility increases as the } \\
\text { temperature increase, as well as the } \\
\text { highest and lowest solubility in pure } \\
\text { 1-methyl-2-pyrrolidinone and pure } \\
\text { methanol, respectively. }\end{array}$ & {$[10]$} \\
\hline & https://t & & & & 43 & \\
\hline
\end{tabular}




\begin{tabular}{|c|c|c|c|c|c|c|}
\hline $\begin{array}{l}\text { Sr. } \\
\text { No. }\end{array}$ & Name & $\begin{array}{l}\text { Name of } \\
\text { Compound }\end{array}$ & Use of Solvent & $\begin{array}{c}\text { Temperature } \\
\text { range } \\
\text { in Kelvin }\end{array}$ & Observation & Reference \\
\hline 5 & $\begin{array}{l}\text { Faiyaz S. } \\
\quad \text { et al. }\end{array}$ & Glipizide & $\begin{array}{l}\text { Water, methanol, } \\
\text { transcutol-HP ethanol, 2- } \\
\text { butanol,isopropanol,ethylen } \\
\text { e glycol, poly(ethyleme } \\
\text { glycol)-400, ethyl acetate, } \\
\text { dimethyl sulfoxide, 1- } \\
\text { butanol, propylene glycol, } \\
\text { pure solvent use }\end{array}$ & $\begin{array}{c}298.2 \\
\text { to } \\
318.2\end{array}$ & $\begin{array}{l}\text { The solubility was recorded } \\
\text { maximum in dimethyl sulfoxide }(281 \\
\left.\times 10^{-4}\right) \text { at } 318.2 \text { Kelvin temperature } \\
\text { among all of the pure solvents and } \\
\text { also noticed that solubility rise up } \\
\text { with a rise in temperature. }\end{array}$ & [11] \\
\hline 6 & $\begin{array}{l}\text { S.Alvani- } \\
\text { Alamdari } \\
\quad \text { et al. }\end{array}$ & mesalazine & $\begin{array}{l}\text { Ethanol and water binary } \\
\text { solvent system use }\end{array}$ & $\begin{array}{l}293.2 \\
\text { to } \\
313.2\end{array}$ & $\begin{array}{l}\text { The solubility had been increased in } \\
\text { order to rise in temperature and } \\
\text { become greater in ethanol, having a } \\
\text { mass fraction of } 0.5\left(1.15 \times 10^{-2}\right) \text { at } \\
313.2 \text { Kelvin. }\end{array}$ & {$[12]$} \\
\hline 7 & $\begin{array}{l}\text { Daniel } \\
\text { R.D. et al. }\end{array}$ & sulphadiazine & $\begin{array}{l}\text { (acetonitrile+water)binary } \\
\text { solvents } \\
\text { (acetonitrile+methanole) }\end{array}$ & $\begin{array}{l}293.15 \\
\quad \text { to } \\
313.15\end{array}$ & $\begin{array}{l}\text { The solubility in the mole fraction } \\
\text { was raised when temperature } \\
\text { increased and increased with } \\
\text { increased acetonitrile proportion. }\end{array}$ & [13] \\
\hline 8 & $\begin{array}{l}\text { Abolghas- } \\
\text { em } \\
\text { Jouyban } \\
\text { et al. }\end{array}$ & acetaminophen & $\begin{array}{l}\text { Two binary solvent systems } \\
\text { use }\end{array}$ & $\begin{array}{l}293.2 \\
\text { to } \\
313.2\end{array}$ & $\begin{array}{l}\text { The solubility was increased in order } \\
\text { to increase in temperature at a } \\
\text { constant solvent mixture. }\end{array}$ & [14] \\
\hline
\end{tabular}

\subsection{The solubility correlation.}

2.2.1. The Apelblat equation.

Apelblat equation is the explanation of solid solubility in non-polar as well as polar solution behavior [15]. The semi-empirical mathematical equation is demonstrated in equation number (2),

$$
\ln x=A+\frac{B}{T}+C \ln T
$$

In eq. 2, The variables $\mathrm{A}, \mathrm{B}$, and $\mathrm{C}$ are the empirical model variables calculated using Origin software, and $\mathrm{T}$ refers to the absolute temperature.

\subsection{2. $\lambda$ h equation.}

The $\lambda \mathrm{h}$ equation [16] explained the dissolution behavior of solid in liquid which is mathematically represented as given in (3),

$$
\ln \left[1+\frac{\lambda\left(1-x_{1}^{c a l}\right)}{x_{1}^{c a l}}\right]=\lambda \mathrm{h}\left(\frac{1}{T}-\frac{1}{T_{m}}\right)
$$

where the absolute temperature was indicated as $\mathrm{T}$, and the melting temperature was $T_{m}$. The empirical model parameters such as $\lambda$ and $\mathrm{h}$ can be obtained using Origin software. $c a l$ is the calculated mole fraction solubility.

Baozeng Ren et al.[17-21], Kui Wu et al.[22], Hongwei Shi et al.[23], Bing Li et al.[24], Piotr Cysewski et al.[25] and Satish G. et al.[26] have predicted the theoretical mole fraction solubility by Apelblat and Buchowski equation, compared the experimental mole fraction solubility values, and concluded that both models fit best.

\subsection{The solubility model correlation.}

The RAD (Relative Average Deviation), A.D. (Absolute relative Deviation), and RMSD (Root Mean Square Deviation) equations were the prediction of the difference between experimented and calculated solubility data values, and it's evaluated the best fitting model. 
2.3.1. Relative Average Deviation (RAD).

The Relative Average Deviation [27-29] was used to predict the result, which is more fitting in the model. The equation of RAD is,

$$
R A D=\frac{1}{N} \sum\left(\frac{\left|x_{i}^{c}-x_{i}^{e}\right|}{x_{i}^{e}}\right)
$$

where the observation reading is denominated by the $\mathrm{N}$ symbol and $x_{i}^{c}=$ theoretical solubility points or $x_{i}^{e}=$ practical solubility points.

\subsubsection{Absolute Relative Deviation (A.D.).}

The Absolute relative Deviation [30, 31] evaluate the fitting effect of the experiment and calculate solubility data value; the equation of A.D. is,

$$
\text { A.D. }=\frac{\left|x_{i}^{e}-x_{i}^{c}\right|}{x_{i}^{e}} \quad \text { or } \quad \text { A.D. }(\%)=\frac{\left|x_{i}^{e}-x_{i}^{c}\right|}{x_{i}^{e}} \times 100
$$

where, $x_{i}^{c}$ is calculated solubility data and $x_{i}^{e}$ is indicated as practical solubility data.

\subsubsection{Root mean square deviation (RMSD).}

The Root Mean Square Deviation (RMSD) (eq.7) [32, 33] was used to predict the difference between experimental and calculated solubility data values,

$$
R M S D=\sqrt{\frac{\sum_{i=1}^{N}\left(x_{i}^{c}-x_{i}^{e}\right)}{N}} \text { or } \operatorname{RMSD}(\%)=100 \times \sqrt{\frac{\sum_{i=1}^{N}\left(x_{i}^{c}-x_{i}^{e}\right)}{N}}
$$

where, the experiment data point value is shown by $\mathrm{N}$ and $x_{i}^{c}$ and $x_{i}^{e}$ are the calculated and practical solubility data values, respectively.

\subsection{Dissolution thermodynamics.}

Thermodynamic properties like $\Delta S^{\circ}, \Delta G^{\circ}, \Delta H^{\circ}$ (entropy change, Gibbs energy change, and enthalpy change, respectively) are the most important parameters thadescribing a solidliquid's dissolution processes and mechanism system equilibrium.

All the apparent thermodynamic quantities of dissolution were predicted in terms of the $T_{h m}$ (mean harmonic temperature) $[34,35]$ which can be obtained by using equation number (7),

$$
T_{h m}=\frac{n}{\sum_{i=1}^{n}\left(\frac{1}{T}\right)}
$$

where the total numbers of temperature range that were taken for the observation are represented with the symbol $\mathrm{n}$.

When a solid solute is dissolved in a liquid solvent, the dissolution process is investigated by an important equation such as a Van't Hoff.

With the help of the modified Van't Hoff equation, the calculations of $\Delta H^{\circ}$ soln and $\Delta G^{\circ}$ soln (apparent standard enthalpy changes of dissolution [36, 37] and the standard Gibbs energy of the dissolution [38, 39]) using Van't Hoff plot between slope and intercept of solubility curves $v s\left[1 / T_{T}\right.$ or $\left.1 / T_{h m}\right]$ as mentioned below in equations (8) and (9), 


$$
\begin{aligned}
& \left(\frac{\partial \ln x}{\partial\left(\frac{1}{T}-\frac{1}{T_{h m}}\right)}\right)_{p}=-\frac{\Delta H_{\text {soln }}^{\circ}}{R} \\
& \Delta G_{\text {soln }}^{\circ}=-R T \times \ln x(\text { intercept })
\end{aligned}
$$

The standard entropy change of solution $[40,41]$ is obtained by using the value of the Gibbs energy and enthalpy of the dissolution, which was mentioned here in equation 10,

$$
\Delta S_{\text {soln }}^{\circ}=\frac{\left(\Delta H_{\text {soln }}^{\circ}-\Delta G_{\text {soln }}^{\circ}\right)}{T_{h m}}
$$

The relative enthalpy and entropy of the solution [42,43] are predicted by using equations (11) and (12) as mentioned below,

$$
\begin{gathered}
\zeta H=\frac{\left|\Delta H_{\text {soln }}^{\circ}\right|}{\left|\Delta H_{\text {soln }}^{\circ}\right|+\left|T \Delta S_{\text {soln }}^{\circ}\right|} \\
\zeta \mathrm{S}=\frac{\left|\Delta S_{\text {soln }}^{\circ}\right|}{\left|\Delta H_{\text {soln }}^{\circ}\right|+\left|T \Delta S_{\text {soln }}^{\circ}\right|}
\end{gathered}
$$

\begin{tabular}{|c|c|c|c|}
\hline Sr.No. & Researcher & Observation & Reference \\
\hline 1 & $\begin{array}{c}\text { F.Martinez et } \\
\text { al. }\end{array}$ & $\begin{array}{l}\text { The dissolution thermodynamics parameters of meloxicam in three binary and } \\
\text { pure solvent systems and observed that } \Delta G^{\circ} \text { (the standard Gibbs energy of } \\
\text { dissolution) and } \Delta H^{\circ} \text { (enthalpy of dissolution) were positive values. The entropy } \\
\text { of dissolution was negative in most cases, except in the mixture of } 0.30 \leq x_{1} \leq \\
0.50 \text { of the (N-methyl formamide+ water) system was found to be positive. The } \\
\text { global dissolution process was endothermic, and it was also concluded that the } \\
\text { dissolution mechanism was free from enthalpy or entropy drive except in } 0.30 \leq \\
x_{1} \leq 0.50 \text { of the (N-methyl form amide+ water) system. }\end{array}$ & [8] \\
\hline 2 & $\begin{array}{l}\text { F. Martinez } \\
\quad \text { et al. }\end{array}$ & $\begin{array}{l}\text { The dissolution thermodynamics parameters of sulfadiazine in ethylene glycol+ } \\
\text { water mixture was an endothermic process which demonstrated the standard } \\
\text { Gibbs energy and enthalpy were positive in each case. The entropies of } \\
\text { dissolution was positive in all cases (except in mixture } w_{1}=0.90 \text { and } 0.95 \text { in } \\
\text { pure ethylene glycol positive entropy obtained) }\end{array}$ & [9] \\
\hline 3 & $\begin{array}{l}\text { F.Martinez et } \\
\quad \text { al. }\end{array}$ & $\begin{array}{l}\text { The global dissolution processes of meloxicam in (carbitol+water) mixture was } \\
\text { always endothermic, which observed the standard Gibbs energy and enthalpy } \\
\text { were positive in every case. The dissolution process is also without entropy or } \\
\text { enthalpy drive except in } x_{1}=0.10 \text { where positive entropy found. }\end{array}$ & [44] \\
\hline 4 & $\begin{array}{c}\text { F.Martinez et } \\
\text { al. }\end{array}$ & $\begin{array}{l}\text { The global dissolution processes of meloxicam in (acetonitrile+water) mixture } \\
\text { was always endothermic and without entropy or enthalpy drive except in the } \\
\text { mixture of } 0.00 \leq x_{1} \leq 0.20 \text { negative entropy observed. The Gibbs energy is } \\
\text { positive in all cases with respect to the enthalpy of the dissolution process. }\end{array}$ & [45] \\
\hline 5 & $\begin{array}{l}\text { Guoquan et } \\
\quad \text { al. }\end{array}$ & $\begin{array}{l}\text { The dissolution process of chloroquine diphosphate in a neat and mixture of } \\
\text { organic solvents was discovered; results indicated that the dissolution } \\
\text { mechanism was spontaneous and endothermic. It was also noted that entropy- } \\
\text { driven was found in every case. The value of Gibbs energy was small, signifying } \\
\text { that the solubility increases and is more suitable for dissolution. }\end{array}$ & [46] \\
\hline 6 & Kamal et al. & $\begin{array}{l}\text { The dissolution process of the cefixime trihydrate in an aqueous deep eutectic } \\
\text { system was non-spontaneous and endothermic and also found that the thermal } \\
\text { effect was more acted than entropy. }\end{array}$ & [47] \\
\hline 7 & $\begin{array}{l}\text { Deman Han } \\
\text { and co- } \\
\text { worker }\end{array}$ & $\begin{array}{l}\text { The global dissolution process was endothermic and entropy-driven in every } \\
\text { system. It was also established that the value of } \Delta G^{\circ} \text { (standard Gibbs energy) as } \\
\text { well as of } \Delta H^{\circ} \text { and } \Delta S^{\circ} \text { (standard enthalpy and entropy) was also positive } \\
\text { obtained in every single case. }\end{array}$ & [48] \\
\hline
\end{tabular}

Observations from different researchers on dissolution thermodynamics properties on various drugs have been shown in Table 3.

Table 3. The dissolution thermodynamics properties of various drugs. 


\section{Conclusions}

Solubility is one of the most important parameters of physicochemical properties. The solubility and dissolution thermodynamics properties of various compounds or drugs have key roles in chemical science, physics, pharmaceutical, food science, petrochemicals, material science, and many more. With the help of the shake flask method, the prediction of experimental mole fraction solubility of drugs determined in various pure or mixed solvent systems at different temperature ranges and using Apelblat and Buchowski equation the theoretical solubility was assumed. Further, the comparison of experimental and theoretical mole fraction solubility of the drug was made. The dissolution thermodynamics parameters such as the Standards Gibbs energy of dissolution, the standards enthalpy of dissolution, and the entropy of dissolution described the global dissolution processes such as endothermic or exothermic without or with enthalpy or entropy-driven. This information can be useful in industries for modification of drugs or compounds and crystallization and recrystallization.

\section{Funding}

This research received no external funding.

\section{Acknowledgments}

The authors are thankful to Mehsana Urban Institute of Sciences, Ganpat University, Mehsana, for providing library facilities and support for research work.

\section{Conflicts of Interest}

The authors declare no conflict of interest.

\section{References}

1. Prausnitz, J.M.; Tavares, F.W. Thermodynamics of fluid-phase equilibria for standard chemical engineering operations. AIChE Journal 2004, 50, 739-761, https://doi.org/10.1002/aic.10069.

2. Kolář, P.; Shen, J.-W.; Tsuboi, A.; Ishikawa, T. Solvent selection for pharmaceuticals. Fluid Phase Equilibria 2002, 194-197, 771-782, https://doi.org/10.1016/S0378-3812(01)00716-6.

3. Li, R.; Fu, L.; Zhang, J.; Wang, W.; Chen, X.; Zhao, J.; Han, D. Solid-liquid equilibrium and thermodynamic properties of dipyridamole form II in pure solvents and mixture of ( $\mathrm{N}$-methyl pyrrolidone + isopropanol). The Journal of Chemical Thermodynamics 2020, 142, 105981, https://doi.org/10.1016/j.jct.2019.105981.

4. Li, R.; Tang, T.; Yin, X.; Yao, L.; Lin, Z.; Zhang, L.; Gao, X.; Xu, X.; Zhao, J.; Han, D. Solubility of naftopidil in pure and mixed solvents at $273.15-313.15 \mathrm{~K}$ and its correlation with the Jouyban-Acree and CNIBS/R-K models. The Journal of Chemical Thermodynamics 2020, 145, 105969, https://doi.org/10.1016/j.jct.2019.105969.

5. Li, R.; Chen, X.; He, G.; Wu, C.; Gan, Z.; He, Z.; Zhao, J.; Han, D. The dissolution behavior and thermodynamic properties calculation of praziquantel in pure and mixed organic solvents. The Journal of Chemical Thermodynamics 2020, 144, 106062, https://doi.org/10.1016/j.jct.2020.106062.

6. Bao, Y.; Xu, R.; Zhao, H. 2-Amino-6-chlorobenzoic Acid Dissolved in Numerous Individual Solvents: Equilibrium Solubility, Thermodynamic Modeling, and Mixing Properties. Journal of Chemical \& Engineering Data 2020, 65, 3252-3260, https://doi.org/10.1021/acs.jced.0c00320.

7. Gong, H.G.B.Y. Solvent Systems and Their Selection in Pharmaceutics and Biopharmaceutics, Springer New York, New York, NY 2007, 6, https://doi.org/10.1007/978-0-387-69154-1.

8. Tinjacá, D.A.; Martínez, F.; Almanza, O.A.; Jouyban, A.; Acree, W.E. Solubility of meloxicam in aqueous binary mixtures of formamide, N-methylformamide and N,N-dimethylformamide: Determination, correlation, thermodynamics and preferential solvation. The Journal of Chemical Thermodynamics 2021, 154, 106332, https://doi.org/10.1016/j.jct.2020.106332. 
9. Cruz-González, A.M.; Vargas-Santana, M.S.; Ortiz, C.P.; Cerquera, N.E.; Delgado, D.R.; Martínez, F.; Jouyban, A.; Acree Jr, W.E. Solubility of sulfadiazine in (ethylene glycol + water) mixtures: Measurement, correlation, thermodynamics and preferential solvation. Journal of Molecular Liquids 2021, 323, 115058, https://doi.org/10.1016/j.molliq.2020.115058.

10. Wu, Z.; Shen, C.; Li, W.; Wu, J.; Zhao, H. Solubility and Thermodynamic Aspects of 5,7-Dibromo-8hydroxyquinoline in Thirteen Neat Solvents at Temperatures from 288.15 to 328.15 (333.15) K. Journal of Chemical \& Engineering Data 2020, 65, 2088-2097, https://doi.org/10.1021/acs.jced.9b01190.

11. Kalam, M.A.; Alshamsan, A.; Alkholief, M.; Alsarra, I.A.; Ali, R.; Haq, N.; Anwer, M.K.; Shakeel, F. Solubility Measurement and Various Solubility Parameters of Glipizide in Different Neat Solvents. ACS Omega 2020, 5, 1708-1716, https://doi.org/10.1021/acsomega.9b04004.

12. Alvani-Alamdari, S.; Rezaei, H.; Rahimpour, E.; Hemmati, S.; Martinez, F.; Barzegar-Jalali, M.; Jouyban, A. Mesalazine solubility in the binary mixtures of ethanol and water at various temperatures. Physics and Chemistry of Liquids 2021, 59, 12-25, https://doi.org/10.1080/00319104.2019.1675157.

13. Delgado, D.R.; Caviedes-Rubio, D.I.; Ortiz, C.P.; Parra-Pava, Y.L.; Peña, M.Á.; Jouyban, A.; Mirheydari, S.N.; Martínez, F.; Acree, W.E. Solubility of sulphadiazine in (acetonitrile + water) mixtures: measurement, correlation, thermodynamics and preferential solvation. Physics and Chemistry of Liquids 2020, 58, 381-396, https://doi.org/10.1080/00319104.2019.1594227.14.

14. Barzegar-Jalali, A. Jouyban, Solubility study of acetaminophen in the mixtures of acetonitrile and water at different temperatures, Journal of Molecular Liquids 2021, 324, 114708, https://doi.org/10.1016/j.molliq.2020.114708.

15. Apelblat, A.; Manzurola, E. Solubilities ofo-acetylsalicylic, 4-aminosalicylic, 3,5-dinitrosalicylic, andptoluic acid, and magnesium-DL-aspartate in water fromT=(278 to 348) K. The Journal of Chemical Thermodynamics 1999, 31, 85-91, https://doi.org/10.1006/jcht.1998.0424.

16. Buchowski, H.; Ksiazczak, A.; Pietrzyk, S. Solvent activity along a saturation line and solubility of hydrogenbonding solids. The Journal of Physical Chemistry 1980, 84, 975-979, https://doi.org/10.1021/j100446a008.

17. Sha, J.; Ma, T.; Zhao, R.; Zhang, P.; Sun, R.; Jiang, G.; Wan, Y.; He, H.; Yao, X.; Li, Y.; Li, T.; Ren, B. The dissolution behaviour and apparent thermodynamic analysis of doxifluridine in twelve pure solvents at various temperatures, The Journal of Chemical Thermodynamics 2020, 144, 106073, https://doi.org/10.1016/j.jct.2020.106073.

18 . Sha, J.; Ma, T.; Huang, Z.; Hu, X.; Zhang, R.; Cao, Z.; Wan, Y.; Sun, R.; He, H.; Jiang, G.; et al. Solubility determination, model evaluation, Hansen solubility parameter and thermodynamic properties of benorilate in six pure solvents and two binary solvent mixtures. The Journal of Chemical Thermodynamics 2021, 153, 106301, doi: https://doi.org/10.1016/j.jct.2020.106301.

19. Sun, R.; He, H.; Wan, Y.; Wang, Y.; Li, L.; Sha, J.; Jiang, G.; Li, Y.; Li, T.; Ren, B. Solubility of melatonin in ethyl acetate $+(\mathrm{N}, \mathrm{N}$-dimethylformamide, 2-methoxyethanol, 2-ethoxyethanol and methanol): Determination, correlation, thermodynamic properties and Hansen solubility parameter at saturation. The Journal of Chemical Thermodynamics 2021, 156, 106372, https://doi.org/10.1016/j.jct.2020.106372.

20. Sha, J.; Cao, Z.; Hu, X.; Huang, Z.; Chang, Y.; Wan, Y.; Sun, R.; Jiang, G.; He, H.; Li, Y.; Li, T.; Ren, B. Solid-liquid equilibrium solubility measurement, model evaluation and Hansen solubility parameter of thiamethoxam in three binary solvents. The Journal of Chemical Thermodynamics 2021, 158, 106364, https://doi.org/10.1016/j.jct.2020.106364.

21. Huang, Z.; Sha, J.; Chang, Y.; Cao, Z.; Hu, X.; Li, Y.; Li, T.; Ren, B. Solubility measurement, model evaluation and Hansen solubility parameter of ipriflavone in three binary solvents. The Journal of Chemical Thermodynamics 2021, 152, 106285, https://doi.org/10.1016/j.jct.2020.106285.

22. Wu, K.; Li, Y. Solubility and solution thermodynamics of isobutyramide in 15 pure solvents at temperatures from 273.15 to $324.75 \mathrm{~K}$. Journal of Molecular Liquids 2020, 311, 113294, https://doi.org/10.1016/j.molliq.2020.113294.

23. Shi, H.; Xie, Y.; Xu, J.; Zhu, J.; Wang, C.; Wang, H. Solubility enhancement, solvent effect and thermodynamic analysis of pazopanib in co-solvent mixtures. The Journal of Chemical Thermodynamics 2021, 155, 106343, https://doi.org/10.1016/j.jct.2020.106343.

24. Yu, S.; Xing, W.; Xue, F.; Cheng, Y.; Li, B. Solubility and thermodynamic properties of nimodipine in pure and binary solvents at a series of temperatures. The Journal of Chemical Thermodynamics 2021, 152, 106259, https://doi.org/10.1016/j.jct.2020.106259.

25. Cysewski, P.; Jeliński, T.; Procek, D.; Dratwa, A. Solubility of Sulfanilamide and Sulfacetamide in neat solvents: Measurements and interpretation using theoretical predictive models, first principle approach and 
artificial neural networks. Fluid Phase Equilibria 2021, 529, 112883, https://doi.org/10.1016/j.fluid.2020.112883.

26. Ponnusamy, K. Determination of chlorzoxazone crystal growth kinetics and size distribution under controlled supersaturation at 293.15 K, Pharm. Sci. 2021, https://doi.org/10.34172/PS.2021.2.

27. Yu, S.; Xu, X.; Xing, W.; Xue, F.; Cheng, Y. Solubility, thermodynamic parameters, and dissolution properties of gliclazide in seventeen pure solvents at temperatures from 278.15 to $318.15 \mathrm{~K}$. Journal of Molecular Liquids 2020, 312, 113425, https://doi.org/10.1016/j.molliq.2020.113425.

28. Blokhina, S.V.; Ol'khovich, M.V.; Sharapova, A.V.; Levshin, I.B.; Perlovich, G.L. Thermodynamic insights to solubility and lipophilicity of new bioactive hybrids triazole with thiazolopyrimidines. Journal of Molecular Liquids 2021, 324, 114662, https://doi.org/10.1016/j.molliq.2020.114662.

29. Yang, G.; Zhang, J.; Huang, C.; Song, X.; Xu, R. Equilibrium Solubility Investigation and Thermodynamic Computational Modeling of Halosulfuron-methyl in a Series of Cosolvent Mixtures at a Temperature Range of 278.15-323.15 K. Journal of Chemical \& Engineering Data 2021, 66, 271-279, https://doi.org/10.1021/acs.jced.0c00633.

30. Yang, W.-Z.; Fan, G.-Q.; Zhang, T.-T.; Li, D.-B.; Pei, L.-L.; Huang, R.-Y.; Yin, D.-P.; Zhang, L.; Peng, G.N.; Shu, G.; et al. Determination of the solubility and thermodynamic properties of albendazole in a binary solvent of ethanol and water. Physics and Chemistry of Liquids 2021, 59, 1-11, https://doi.org/10.1080/00319104.2019.1660979.

31. Shekaari, H.; Mokhtarpour, M.; Faraji, S.; Zafarani-Moattar, M.T. Enhancement of curcumin solubility by some choline chloride-based deep eutectic solvents at different temperatures. Fluid Phase Equilibria 2021, 532, 112917, https://doi.org/10.1016/j.fluid.2020.112917.

32. He, H.; Sun, R.; Wan, Y.; Jiang, G.; Sha, J.; Li, Y.; Li, T.; Ren, B. Solubility determination and thermodynamic modelling of 5-chloro-8-hydroxyquinoline in binary solvent mixtures from $\mathrm{T}=278.15$ to $323.15 \mathrm{~K}$. The Journal of Chemical Thermodynamics 2021, 154, 106315, https://doi.org/10.1016/j.jct.2020.106315.

33. Przybyłek, M.; Walczak, P.; Ziółkowska, D.; Grela, I.; Cysewski, P. Studies on the solid-liquid equilibria and intermolecular interactions Urea binary mixtures with Sulfanilamide and Sulfacetamide. The Journal of Chemical Thermodynamics 2021, 153, 106308, https://doi.org/10.1016/j.jct.2020.106308.

34. Delgado, D.R.; Bahamón-Hernandez, O.; Cerquera, N.E.; Ortiz, C.P.; Martínez, F.; Rahimpour, E.; Jouyban, A.; Acree, W.E. Solubility of sulfadiazine in (acetonitrile + methanol) mixtures: Determination, correlation, dissolution thermodynamics and preferential solvation. Journal of Molecular Liquids 2021, 322, 114979, https://doi.org/10.1016/j.molliq.2020.114979.

35. Sheikhi-Sovari, A.; Jouyban, A.; Martinez, F.; Hemmati, S.; Rahimpour, E. Solubility of mesalazine in ethylene glycol + water mixtures at different temperatures. Journal of Molecular Liquids 2021, 323, 114597 , https://doi.org/10.1016/j.molliq.2020.114597.

36. Moradi, M.; Rahimpour, E.; Hemmati, S.; Martinez, F.; Barzegar-Jalali, M.; Jouyban, A. Solubility of mesalazine in polyethylene glycol $400+$ water mixtures at different temperatures. Journal of Molecular Liquids 2020, 314, 113546, https://doi.org/10.1016/j.molliq.2020.113546.

37. Osorio, I.P.; Martínez, F.; Delgado, D.R.; Jouyban, A.; Acree, W.E. Solubility of sulfacetamide in aqueous propylene glycol mixtures: Measurement, correlation, dissolution thermodynamics, preferential solvation and solute volumetric contribution at saturation. Journal of Molecular Liquids 2020, 297, 111889, https://doi.org/10.1016/j.molliq.2019.111889.

38. Barzegar-Jalali, M.; Mazaher Haji Agha, E.; Adibkia, K.; Hemmati, S.; Martinez, F.; Jouyban, A. Solubility of mesalazine in \{acetonitrile + water\} mixtures at various temperatures. Physics and Chemistry of Liquids 2020, 1-16, https://doi.org/10.1080/00319104.2020.1808657.

39. Jouyban, K.; Mazaher Haji Agha, E.; Hemmati, S.; Martinez, F.; Kuentz, M.; Jouyban, A. Solubility of 5aminosalicylic acid in N-methyl-2-pyrrolidone + water mixtures at various temperatures. Journal of Molecular Liquids 2020, 310, 113143, https://doi.org/10.1016/j.molliq.2020.113143.

40. Jouyban, K.; Acree, W.E.; Martínez, F. Dissolution thermodynamics and preferential solvation of ketoconazole in some $\{$ ethanol (1) + water (2)\} mixtures. Journal of Molecular Liquids 2020, 313, 113579, https://doi.org/10.1016/j.molliq.2020.113579.

41. Jouyban, A.; Acree, W.E.; Martínez, F. Dissolution thermodynamics and preferential solvation of gliclazide in (Transcutol ${ }^{\circledR}+$ water) mixtures. Physics and Chemistry of Liquids 2021, 59, 607-621, https://doi.org/10.1080/00319104.2020.1793336.

42. Mirheydari, S.N.; Barzegar-Jalali, M.; Martinez, F.; Jouyban, A. Solubility of lamotrigine in acetonitrile + water mixtures at various temperatures. Physics and Chemistry of Liquids 2020, 58, 769-781, https://doi.org/10.1080/00319104.2019.1636380. 
43. Rezaei, H.; Jouyban, A.; Martinez, F.; Barzegar-Jalali, M.; Hemmati, S.; Rahimpour, E. Solubility and thermodynamic profile of mesalazine in carbitol + ethanol mixtures at different temperatures. Journal of Molecular Liquids 2021, 324, 114763, https://doi.org/10.1016/j.molliq.2020.114763.

44. Tinjacá, D.A.; Martínez, F.; Almanza, O.A.; Jouyban, A.; Acree, W.E. Solubility of meloxicam in (Carbitol $\AA+$ water) mixtures: Determination, correlation, dissolution thermodynamics and preferential solvation. Journal of Molecular Liquids 2021, 324, 114671, https://doi.org/10.1016/j.molliq.2020.114671.

45. Tinjacá, D.A.; Martínez, F.; Almanza, O.A.; Jouyban, A.; Acree, W.E. Dissolution thermodynamics and preferential solvation of meloxicam in (acetonitrile + water) mixtures. Physics and Chemistry of Liquids 2020, 1-20, https://doi.org/10.1080/00319104.2020.1808658.

46. Guoquan, Z.; Tinggong, W.; Danfeng, S.; Jian, S.; Zehui, Y. The solubility and dissolution thermodynamic properties of chloroquine diphosphate in different organic solvents. The Journal of Chemical Thermodynamics 2021, 156, 106368, https://doi.org/10.1016/j.jct.2020.106368.

47. Kamal, A.; Haghtalab, A. Experimental and thermodynamic modeling of cefixime trihydrate solubility in an aqueous deep eutectic system. Journal of Molecular Liquids 2020, 304, 112727, https://doi.org/10.1016/j.molliq.2020.112727.

48. Li, R.; Jin, Y.; Yu, B.; Xu, Q.; Chen, X.; Han, D. Solubility determination and thermodynamic properties calculation of macitentan in mixtures of ethyl acetate and alcohols. The Journal of Chemical Thermodynamics 2021, 156, 106344, https://doi.org/10.1016/j.jct.2020.106344. 